\title{
Stakeholder Engagement beyond the Tension between Idealism and Practical Concerns
}

\author{
Silvia Biraghi ${ }^{1}$, Rossella C. Gambetti ${ }^{1} \&$ Stefania Romenti ${ }^{2}$ \\ ${ }^{1}$ Università Cattolica del Sacro Cuore, LABCOM, Italy \\ ${ }^{2}$ Università IULM, Italy \\ Correspondence: Silvia Biraghi, Università Cattolica del Sacro Cuore, LABCOM, Italy. E-mail: \\ silvia.biraghi@unicatt.it \\ Received: July 20, 2016 \\ Accepted: January 24, 2017 \\ Online Published: January 26, 2017 \\ doi:10.5539/ijbm.v12n2p14 \\ URL: http://dx.doi.org/10.5539/ijbm.v12n2p14
}

\begin{abstract}
This paper digs into the existing controversial literature on stakeholder engagement (SE) to understand and critically confront with ambivalence in the concept. This is done by exploring how SE is conceptually framed and pragmatically pursued in the representations of current business practices. The study is designed according to a qualitative interpretive approach based on depth interviews with a purposively selected theoretical sample of key informants with established expertise in stakeholder relationship management practices. According to our findings, SE appears torn between an idealistic impetus on the fringe of a utopian vision of the business, and its often trivial translation into practice urged by the pragmatic necessity to meet accountability requirements. This tension stems from corporate governance logics and organizational business models of firms, which are often not prone to guarantee the participatory and genuinely dialogic exchange between company and stakeholders advocated by the idealistic mandate of SE. In terms of contribution the paper provides a critical inductive reconstruction of current meanings and clashes embedded in enacting SE.
\end{abstract}

Keywords: business-society relations, moral engagement, stakeholder dialogue, stakeholder engagement, strategic engagement

\section{Introduction}

The role corporations should play in society in terms of their social engagement and ethical responsibilities has been increasingly questioned in recent times (Aßländer \& Curbach, 2014; Buchholtz \& Carroll, 2009; Leisinger, 2009). Governments, activists, communities and stakeholders in general expect companies to account for the social consequences of their activities (Porter \& Kramer, 2006) and to act as if they were metaphorically citizens in that their commitments to society resemble those of citizens (Moon, Crane, \& Matten, 2005). An increasing number of critical corporate events are pointing at the necessity of securing society's trust. Emission scandals (Volkswagen, BBC, 2015 December 10), rainforest damage due to palm oil abuse (Mattel Barbie, Greenpeace, 2011 June 7), accounting and corruption scandals (Toshiba and Fifa, Fortune, 2015 December 27) are compelling firms to rethink their role in society. For example, the Oxfam report "Behind the Brands" scrutinizes the world's ten biggest food corporations on issues from workers' rights to water usage to corporate transparency. According to Oxfam, the agricultural industry, especially Kellogg and General Mills, is responsible for about a quarter of the world's greenhouse gas emissions. Oxfam is pressing businesses and trade groups to engage with stakeholders on the issues of environmental and climate change responsibility (Time, 2014, May 20). These expectations are reconfiguring the rationale and the dynamics of business-society relations (Logsdon \& Wood, 2002; Matten \& Crane, 2005) since corporations are now recognizing that it is their duty to fulfil obligations to society rather than to just government (Stokes, 2002). This imbues firms with an ethical ethos that leads to corporate social responsiveness (Fukukawa, Balmer, \& Gray, 2007) to engage stakeholders in processes and structures related to strategic management to better respond to expectations (Palazzo \& Basu, 2007; Vallaster, Lindgreen, \& Maon, 2012). Research reports by McKinsey shows that on average 30\% of a company's value is at stake when it comes to its relationships with society. This underlines stakeholder engagement (SE) as a rising priority for CEOs and boards (McKinsey, 2016, July).

Stakeholder engagement (SE) has been understood as a mutually beneficial and just scheme of cooperation which takes the form of a moral partnership of equals (Phillips, 1997) based on collaborative work for the sake of the 
common good (Sison \& Fontrodona, 2012). Lord John Browne, former CEO of BP, states that companies need to incorporate societal connections formally into their operations and strategy. In Indonesia, for example, where BP was seeking to construct a liquefaction plant to enable gas exports, the company was working against a backdrop of ethnic conflict, secessionist demands and a history of environmental damage caused by Western mining companies. BP's response was to establish an independent advisory panel that would hear community concerns, examine BP's activities and report its findings publicly and fully, and without interference from the company (Fortune, 2016 March 12). Daniel Vasella, Former chairman of Novartis, believes that the final hallmark of SE is a radical approach to communication with the external world (McKinsey, 2013 March).

Along these lines, corporations have interpreted SE as a corporate practice undertaken to interact with stakeholders and involve them in a positive manner in company activities (Greenwood, 2007). However, for firms is no longer sufficient to merely interact with stakeholders: interaction with stakeholders is a logically necessary activity of business (Noland \& Phillips, 2010). However, to make SE more substantive and meaningful, corporations must confront with its philosophical and pragmatic essence and with its moral and strategic nature.

This paper digs into the existing controversial conceptualizations of SE, which according to dominant perspectives is torn between moral and strategic motives. The paper puts forth three perspectives of analysis informing the in-depth interpretive study aimed at inductively substantiating ambivalence in SE. This study attempts to discern the nature of moral and strategic SE as depicted in the representations of current corporate SE practices. This empirical investigation outlines the clashes that inherently undermine the idealistic ethos of SE. Doing that the paper contributes to existing knowledge in the field by providing a critical inductive reconstruction of current meanings and actual controversies in SE practice.

\section{Stakeholder Engagement: Current Dominant Perspectives}

SE acknowledges stakeholder relationships as the interplay among collectives of actors within specific societal settings, where companies need to negotiate their strategies and decisions in order to gain and retain legitimacy (Meyer \& Rowan, 1977). This conceptual view recognizes that the interests of the firm are inseparable from those of stakeholders (Noland \& Philips, 2010), who under conditions of good faith commit to reciprocal obligations driven by the desire to reach an agreement on a common concern (Dawkins, 2014) to resolve communitarian problems (Moon et al., 2005). SE emerges then as a deliberative and democratic approach to stakeholder relationships aimed at a more equitable exchange among business and society to influence constructively corporate actions (Corus \& Ozanne, 2012). That by combining the utility functions of stakeholders with their vital role as value co-builders (Garriga, 2014) and co-creators of the development of corporate identities and brands (Balmer, Johansen, \& Nielsen, 2016).

At present, two dominant perspectives in SE literature stand out. First, a tendency to conceptualize SE as moral engagement. This approach represents SE as a moral act of common humanity and respect toward society at large (Deetz, 2008; Noland \& Philips, 2010) driven by the will to nurture social improvement. Morality as driver of SE advocates for dialogue, social justice, whiteness, and pedagogy of diversity to be introduced in business processes by conceiving SE as the catalyst of an ideal democratic principle of corporate management (O'Dwyer, 2005). In moral SE, corporations become part of the political community and are inspired by the will to contribute to society getting involved in public discourse, civil endeavors, and political rule-making (Aßländer \& Curbach, 2014) to develop and maintain high-quality stakeholder relationships (Waddock, 2002). While in the past stakeholders were seen primarily as passive subjects, moral engagement raises stakeholders at the same dialogical level of the firm, encouraging partnerships and collaborations (Andriof \& Waddock, 2002) toward the pursuit of mutually legitimate goals based on a more inclusive decision-making process (Andriof \& Waddock, 2002; Harrison \& St. John, 1996). $\mathrm{SE}$ is seen then as the response, on behalf of companies, to the growing demand for transparency and accountability on the part of an increasing number of stakeholders (Waddock, 2004), who are willing to be involved, to relate with companies, and to be informed more openly about business conducts (Burchell \& Cook, 2006).

Second, a more recent angle on SE, namely the ethical strategist perspective, argues that morality and strategy should be reunited based on the principle that a good strategy must include moral concern in order to be welcomed by stakeholders and grant the company the social license to operate (Hall \& Jeanneret, 2015). That emphasizes participation in the public good by fostering community ties (Crane, Matten, \& Moon, 2004; Wood, Logsdon, Lewellyn, \& Davenport, 2006), and honest and respectful engagement of stakeholders as a vital part a viable firm's strategy (Noland \& Phillips, 2010) informed by the ongoing exchange between business and society jointly shaping purposes, rights, and duties (Bhattacharya, Korschun, \& Sen, 2009). Ethical strategists recognize in SE activities the potential to increase the profitability of the firm and its competitive advantage by building on 
stakeholders' opinions, knowledge, expectations, and demands (Andriof \& Waddock, 2002). In this case the decision to include stakeholders is not only morally driven; rather it is based on the willingness to take advantage of the relationship with stakeholders against competitors in terms of increased trust, support, and encouragement of the innovative capacity for the sake of the business (i.e. design of product innovations, identification of challenges in business development) (Andriof \& Waddock, 2002; Harrison \& Freeman, 2004; Payne \& Calton, 2002). In this regard the activation of multi-stakeholder dialogue has been posited as a mechanism to facilitate stakeholder activation and to inspire companies to solve social problems and improve social welfare (Sloan \& Oliver, 2013). More specifically, multi-stakeholder dialogues are learning environments that enable the firm to tackle with complex problems felt both by the company and its stakeholders, leveraging their participation in the formulation and implementation of business decisions. Multi-stakeholder dialogues rely on scripted interaction that can inform different patterns characteristic of symmetric two-way communication with different stakeholder groups (Johansen \& Nielsen, 2011) with the aim of collecting knowledge previously unavailable that companies can use to innovate and change (Burchell \& Cook, 2006). The learning process that emerges is able to strengthen relations between the firm and stakeholders and to improve corporate governance and development (Payne \& Calton, 2002). The involvement of multiple stakeholders in these dialogues can help to diagnose potential problems or organizational challenges as well as receive suggestions on the initiatives to be undertaken. It also allows managers to receive further input for the formulation and monitoring of corporate strategies in the long term, eventually overcoming traditional "managerial myopia" (Payne \& Calton, 2002) through the processes of finding the right issues and the relevant issue arenas in which companies should participate in the discussion with stakeholders to secure corporate reputation and survival (Luoma-aho \& Vos, 2010).

While showing the potential of SE for the advancement of business and society relations, extant studies also highlight SE as a controversial conceptual territory, where no single perspective seems to stand out for its universal valence. Views on SE range from convincing managers to recognize that their interests are inseparable from those of their stakeholders and acting accordingly (Noland \& Phillips, 2010), to developing interactions with stakeholders aimed at obtaining consent as means to an end; from providing stakeholders with control in managing the corporation (Moriarty, 2014) based on the idealistic democratic view of a morality-driven corporate management uncorrupted by power differences and strategic motivations (Noland \& Phillips, 2010; Hielscher, Beckmann, \& Pies, 2014), to activating self-serving dialogues (Reed, 1999) that can strengthen company's advantage.

This ambivalence of SE impairs the understanding of its substantive conceptual essence and pragmatic potential for business practices. In order to address the ambiguity surrounding the concept, SE requires a depth interpretive look to uncover the perceptions currently linked to SE (see the perceptual area of investigation in the methodological and findings sections), to explore ambivalence and constraints related to the concept and its practice (see the critical appraisal area), and to reconstruct the engagement mechanisms that connect the corporation with its stakeholders (see the actualization area) (Dawkins, 2014). Therefore studies are needed that adopt a more emergent stance on SE grounded into the field of its actual practices.

\section{Objective of the Study and Method}

This study is aimed at understanding and critically confronting with ambivalence in SE by exploring how it is conceptually framed and pragmatically pursued in the representations of current business practices.

On this purpose, this study is designed according to a qualitative interpretive approach based on 15 depth interviews that allowed exploring the complex nuances of the SE phenomenon with maximum flexibility and analytical detail (Seale, Gobo, Gubrium, \& Silverman, 2007). When a complex phenomenon is still controversially framed and defined, an interpretive insight is the way forward to achieve a thorough and rich understanding of both its essence and conceptual boundaries without imposing rigid and desk-defined assumptions (Tracy, 2013). Furthermore an interpretive approach provided the opportunity to develop a context-driven glance on the SE phenomenon by encompassing the wide range of sensitivities, experiences, and standpoints of the actors involved in SE practices. This approach was then useful in eliciting and aggregating SE actors' viewpoints in a situation of lack of viable knowledge on an emerging and practice-relevant topic (Seale et al., 2007).

Key informants participating in the study were purposively selected following the principles of theoretical sampling (Glaser \& Strauss, 1970) based on their established expertise in stakeholder relationship management practices in order to cover the wide range of intellect and experience that can be generated and leveraged in conceptualizing and appraising engagement in the management field (Morse, Stern, Corbin, Charmaz, Bowers, \& Clarke, 2009). 
Table 1. SE key informants

\begin{tabular}{ll}
\hline Key informant position & Industry \\
\hline Internal Communication \& Employer Branding Manager & banking \\
Senior consultant & corporate strategy \\
Stakeholder relationship officer & education \\
HR manager & fashion accessories \\
Supply Chain Director & food \\
Independent consultant & green \& environmental practices \\
Patient wellness manager & healthcare \\
Marketing Director & home \& laundry care \\
Senior Reputation Manager & mechanics \& automotive \\
Senior consultant & media, publishing \& culture \\
Community manager & municipality \\
CSR manager & pharmaceutical \\
\hline & wine $\&$ spiritity energy \\
\hline
\end{tabular}

Since the expertise of participants is of paramount importance with regard to the "quality" of the knowledge developed, 11 senior corporate executives operating in different business functions and industries were involved, and 4 senior consultants with a wide portfolio of clients (see Table 1). These informants are executives and senior managers/partners who have been active in the field of SE practice for more than ten years; they operate in highly stakeholder sensitive business functions (e.g. supply chain, marketing, investor relations); and they are actively participating in the reflection on the phenomenon, taking part in public debates, workshops, and symposia. That allowed us sampling a high variability of experiences, views, and sensitivities on the phenomenon from experts who are involved both in SE current management and in its reflective analysis, as far as saturation in the data was achieved (Cassel \& Symon, 2004) when all information gathered resulted in repeated occurrences and commonalities in themes, open issues, actual opportunities and constraints related to SE (Morse, 1995).

In-depth interviews were carried out in order to explore in detail informants' perceptions and experiences of SE and to discuss its ambivalent nature. The interviews lasted about two hours and were carried out face-to-face in the business setting of the interviewees at their office. The interviews covered the following thematic areas of investigation: a) a perceptual area including such sub-themes as values and meanings attached to SE, relevant issues and business priorities, perceived role of SE in corporate strategy; b) a critical appraisal area, which is aimed at elaborating and discussing the criticalities of SE related to the tension between its idealistic afflatus and its translation into practice; c) an actualization area covering such sub-themes as SE in practice (i.e. actions undertaken by company and stakeholders).

Interviews were then integrally transcribed and subjected to interpretive analysis by the researchers who carried them out. More specifically data analysis was an iterative and inductive process based on an ongoing confrontation of the research team with the aim of integrating interpretive insights and reach a common view of the research material (Mayan, 2009). Various verification strategies were adopted in this analytical process, such as concurrent data collection and analysis, constant comparative analysis, and iterative analysis: those techniques helped 
researchers organize complexity into common themes (Coffey \& Atkinson, 1996; Maxwell \& Miller, 2008) based on the reasoning on the insights emerging from data, on the testing and challenging of preliminary interpretations, and on the abstracting and conceptualizing in order to reach a coherent final interpretation of the collected materials that is presented in the findings.

\section{Findings}

\subsection{Perceptual Area: Framing Stakeholder Engagement}

Based on the interviews, SE has been first explored according to a perceptual area of investigation aimed at defining the phenomenon by illustrating the meanings and the key issues/priorities associated to it. At a general level SE emerges as a dynamic process-based concept that relies on a company effort to listen to stakeholders, gather their viewpoints, sense their opinions and attitudes to elaborate and interpret them with the aim of taking better informed decisions aligned with stakeholders' expectations.

"It means to me establishing a dialogue to understand another party, the expectations and how this expectation can be meet by actions so it's confrontation about possible answers" (Key informant 2)

According to participants, SE can be depicted as a dialogic process progressively enacted by the company in relating with its stakeholders. This dialogue is based on an on-going negotiation and adjustment process, where a mutual understanding of the reciprocal desiderata is achieved through a constant comparison between the expectations held, the decisions undertaken, and the actions performed.

"Generalization kills stakeholder engagement! Because a general approach neglects what is really relevant and the absence of relevance makes engagement meaningless [...] if I compete in the fashion business what is relevant is not having some bags designed by convicts. The core and genuine problem is fairness in the value chain so it doesn't make sense engaging people with frills while missing to face massive concerns" (Key informant 1)

Since "having a stake" is vital in activating stakeholders' will to take part in this confrontation process, participants depict SE as a firmly context-based phenomenon, which implies the ability of the firm to select a few key hot topics that indeed represent the mutual interest touch-point where a company and its stakeholders converge to collaborate on common priorities. The selection of priorities allows for the focalization of the SE path on the true relevant and sensitive issues, which are both context- and firm-specific.

In this regard evidence shows that the currently widely spread and superficial "one size fits all" approach to SE seems to underpin a mere image-building effort of companies that conceive SE actions as part of a green- and social- washing checklist, eluding the real themes that lie at the heart of stakeholders and neglecting to really commit themselves to SE.

"Inside the firm welfare is huge so protecting employees especially in time of crisis and distress [...] supplier and all our partners are also relevant to involve in the development of our business, they're vital. [...] over the last few years everything that is social, it's locally relevant is the heart of people for debate. You see it's all connected to people" (Key informant 7)

Notwithstanding the context-based nature of the phenomenon, some recurrent issues emerge in interviewees' accounts that are commonly seen as relevant in engaging stakeholders. Three main priorities have been identified, which progressively enlarge the scope of interest and action of the company: a focus on general employees' well-being, covering such aspects as work and life balance, new job opportunities, and personal development inside the firm; a deeper understanding and optimization of the value chain, encompassing the attention to creating and maintaining positive relationships with upstream and downstream supply chain partners; a concern for the role of the company in its social and environmental context, including such topics as healthcare and investments in community development. All these topics need to be managed according to a focused and context-driven approach in order to undertake actions that are valuable for stakeholders and viable.

"Somehow engagement is the starting point of sustainability, it's the backbone of what is human and ethical in business [...] it's how we do sustainable management" (Key informant 12)

In this regard, SE seems to emerge as a concrete enabling factor of putting responsibility intentions into practice, which grounds sustainability into company facts acting as a sensing mechanism for the company to understand if the balance between economic and social performances is achieved.

"It's about being somehow attentive toward your interlocutors, but it's necessary about being ethical [...] it was five years ago in the news, Goldman Sachs grants up to 200.000 euros to support for the issue of gender change. It was the result of a listing activity with some stakeholders" (Key informant 8)

The perceptual area of inquiry allowed framing SE as a process-based concept characterized by a dialogic nature 
relying on reciprocity driven by selective relevance. That means SE emerged as a context-related concept, which dynamically evolves according to constant negotiation logics between companies' and stakeholders' primary stakes.

\subsection{Critical Appraisal Area: Uncovering Ambivalence under the Surface of Stakeholder Engagement}

The study then adopted a critical appraisal perspective in exploring the research material aimed at identifying open challenges and tensions embedded in the SE concept and practice. At a more depth level of analysis SE appears as an ambivalent concept, which holds in its very essence contrasting principles and logics at conceptual and operational level.

From the conceptual standpoint, in interviewees' representations SE is torn between an idealistic and aspirational tension rooted in the corporate moral premise of being and acting "good" in the society, and its pragmatic enacting in day-to-day business practices. Idealism is fostered by a widespread awareness and a deep belief that a more careful analysis of social instances based on a dialogic approach of the company with all its stakeholders represents a priority in corporate strategy.

"Sometimes I've heard corporate executives talk with an over-confident and assertive attitude about stakeholder engagement, its application inside their own company, its results in terms of stakeholder commitment, as it were a natural component of the corporate strategy" (Key informant 4)

This priority is made explicit by corporate executives with an assertive and patronizing attitude, which seems to reveal SE as embedded in corporate strategy development.

"They talk about stakeholder engagement but often they mean they simply want to sensitize employees toward an organizational change, or they mean customer satisfaction and they carry out a couple of focus groups...that actually are not even rigorous focus groups but simply discussion tables [...] or sometimes they mean encounter with their suppliers but they simply organize a convention" (Key informant 5)

SE shows its problematic essence in participants' accounts that uncover a trivialization of SE translation into practice. On one side, company executives are doubtful about how to concretely enact SE beyond idealistic statements; on the other side, when they think they know what to do they are actually simply relabeling well-established business practices (i.e. change management, customer satisfaction, employee empowerment) to appear up-to-date and they are stretching the adoption of traditional research tools (i.e. interviews, focus groups, surveys) to encompass dialogic dynamics that can be hardly activated and understood only through a set of traditional research tools and techniques.

"Often when the term stakeholder engagement is used it stands for the expression of an instrumental orientation of the firm" (Key informant 14)

Moreover, these listening and information gathering moments are seen by participants sometimes as self-contained SE practices that are not encapsulated in corporate decision-making processes and whose adoption is merely instrumental toward contingent corporate aims.

"The results of the dialogic activities toward stakeholders are not usually measured and cannot be effectively measured. Normally these activities enhance corporate intangible assets of the firm, corporate reputation, talent attraction capability, which are extremely difficult to measure since they stem from the convergence of various elements. This dramatically discourages firms to measure their dialogic efforts. So stakeholder engagement can be somewhat seen as a true 'act of faith' of top executives which can be effective, but in the long period" (Key informant 9)

Difficulty in enacting SE is also rooted in the very genesis of the practice, which is driven by the cogent reporting standards i.e. integrated annual reporting, Triple Bottom Line that require specific SE accounts and key performance indicators. This short-term outlook on SE accountability has recently forced companies to strive to find a way to meet this obligation, which tends to be often perceived as a dramatic problem rather than as a challenging opportunity. SE key performance indicators are perceived as very difficult to identify since they rely on the convergence and the interplay among various elements that contribute to enhance the corporate intangible asset portfolio of the firm. Thus interviewees are aware that the impact of SE practices unfolds in the long run, hence current performance indicators - although necessary - are seen as partial and simplistic. This pressure towards evidence-based reporting of SE points at the ambivalence between the necessity to size and assess SE efforts and the awareness of the limits of current measurement standards. This struggle seems to translate into a dualism between a skeptical corporate attitude towards SE feasibility and a genuine "act of faith" on the part of the company on the potential effectiveness of SE. 
"The firm has a governance structure, a decision-making system that is rigid and not democratic at all. Yet there are wide discretionary margins to cope with the current complexity that allow being more sensitive to social instances, discussing and modifying consolidated rules and programs, and stakeholder engagement is an effort of the firm to overcome its self-referential attitude" (Key informant 3)

The skeptical attitude toward SE is exacerbated by a predominant rigid and bureaucratic corporate governance system that is structurally not oriented to sustain SE. This means that when companies commit themselves to SE, they are playing within the discretional edges allowed by their non-democratic governance systems, constantly trading-off between inside rules and stakeholders' expectations. This tension challenges the rigidity of traditional corporate governance models which are hard-pushed by porous organizational boundaries that require wider and wider discretional spaces of company-stakeholder interaction. Moreover, this tension calls for a moral effort of the company to overcome its self-referential attitude in conceiving and running the business.

"Ethical leadership sees stakeholder engagement as an embedded attitude which informs all corporate decisions. The ethical leader most likely does not even call it stakeholder engagement, he simply enacts it naturally in his daily running of the business" (Key informant 6)

The ability to play within the discretional edges of organizational bureaucracy and take up the challenge of SE seems to rely on the type of leadership enacted by the CEO, who is responsible for the viability of SE as an habitus embodied in all corporate processes.

The critical appraisal area of investigation allowed uncovering the doubtful and fragile nature of the SE concept, which appears to be currently stuck in a clash between idealism and trivialization of its practice. This hard to reconcile clash seems to potentially impair the expression of a genuine SE effort, which is perceived as a problematic leap of faith driven by moral concerns. However, morality appears as idealistic given the skeptical corporate attitude and rigid governance rules that permeate companies.

\subsection{Actualization Area: Unfolding Stakeholder Engagement Process}

Finally actualization area was investigated to get an insight into SE dynamics by exploring the roles enacted by SE corporate actors and the nature of the relationship they developed over time with their stakeholders.

Based on participants' accounts, SE is depicted as an autopoietic, self-sustaining and reproducing process, which is initiated and conducted by the firm and marked by a progressive opening of the company toward stakeholders.

"Engagement cannot be imposed [...] it's like stating I'm at your disposal and you're at my disposal as well, and as long as we're handling this precious treasure together we share and share and share" (Key informant 10)

"The company should lead the game, but we understood that we're not playing alone [...] only continuous confrontation can make engagement happen" (Key informant 1)

This opening effort seems to be based on the ongoing negotiation of a stake that metaphorically firm and stakeholders put on the table for discussion, shaping, and fine-tuning. Since the stake is commonly felt as relevant and demanding, this negotiation dynamic is nurtured by reciprocal availability to interact, to devote time to each other, and to reframe mutual expectations. According to participants, dialogue is the fuel that sustains parenthetic interaction and open confrontation to make it possible for the company to understand and also anticipate stakeholders' expectations to perform a better-informed decision-making.

"Stakeholders are growing sophisticated in their expectations so beware of engagement! If you activate this dynamics there's no point of return" (Key informant 7)

Parenthetic dialogue takes the company into a problematic relational territory. In informants' perceptions companies lack the organizational flexibility required to sustain the growing dialogic instances and the progressive opening of decision-making tables. Engaging in dialogue with stakeholders is often felt as problematic in that it can make the firm vulnerable against evolving stakeholders' demands.

"The thing is you can never know in advance what it's going to happen! We are all vulnerable, we feel evaluated, but still we cannot adjust in progress [...] if we want to change something we have to undergo many levels of decisions and approval" (Key informant 3 )

In interviewees' views this seems to suggest that a cautious dialogic approach should be adopted by the company in engaging stakeholders based on a wise experimentation of interaction initiatives, which should be genuinely customized in the eye of stakeholders since no best practices and universal guidelines apparently exist in SE so far.

In participants' accounts, the paucity of guiding principles in pursuing SE has powerfully emphasized the necessity of a flexible, multidisciplinary, and cross-domain organizational figure capable of coordinating the multiple 
dialogic tables where company and stakeholders converge; bridging their different sensitivities and logics; merging their heterogeneous interests, aims and priorities; cultivating common communicative codes; and seeding the parenthetic and dialogic culture of SE at the inter-functional level. That in order to make of SE a task whose mandate is distributed across all organizational levels.

"You must be like a sensor which detects what is going on in the firm, in the business, in the social context so a person who devotes his time to hang around and see, participating in many different tables, eventually as the organizers of these tables or as a discussant or as a guest" (Key informant 6)

Finally, this organizational figure is expected to possess a strong sensitivity and sensibility in both discerning the criticalities that make of issues true stakes for stakeholders and selecting the right representatives of stakeholder categories to involve in the dialogic tables. Indeed, selection, specificity, and personalization are felt as crucial priorities in which to invest to orient SE efforts.

The actualization area of inquiry allowed representing SE as a demanding back-and-forth confrontation dynamic, which although initiated by the company is then nurtured by a continuous injection of expectations by stakeholders. The co-managed relational nature of SE, whose "property" is shared between the company and its stakeholders, traces a problematic dialogic territory that companies are currently approaching by adopting a cautious attitude toward stakeholders.

Table 2 summarizes the clashes emerged from the ambivalent representations of SE concept and practice. At present, these clashes show the ambivalence between the ideal perceptions linked to SE and its translation into practice.

Table 2. Clashes characterizing ambivalence in SE

\begin{tabular}{|c|c|c|c|c|}
\hline Thematic area of investigation & Highlights from findings & $\begin{array}{l}\text { Intertwined } \\
\text { ambivalence }\end{array}$ & areas & SE \\
\hline Perceptual area & Context-specific, selective and dynamic dialogic process & $\begin{array}{l}\text { Perception } \\
\text { actualization }\end{array}$ & clashes & with \\
\hline Critical appraisal area & Morality-driven idealistic intentions clash with trivial practices & Inner clash & & \\
\hline Actualization area & Demanding and Problematic dialogic territory & $\begin{array}{l}\text { Actualization } \\
\text { perception }\end{array}$ & clashes & with \\
\hline
\end{tabular}

\section{Discussion}

The perceptual area of investigation of this research has depicted SE as a dynamic dialogic process that is perceived as negotiated with stakeholders, although started and managed by the firm. This process is marked by a progressive opening of the company toward stakeholders and relies on an issue that company and stakeholders metaphorically put forth for confrontation and adjustment. Such a process is commonly felt as demanding, timeand energy-consuming, and emotionally involving.

In the actualization area dialogue appears as the fuel maintaining this process by allowing parenthetic interaction, reciprocal understanding, and anticipation of stakeholder expectations to better orient corporate decision-making. Furthermore according to the perceptual area, SE dialogic process seems to imply selective relevance, which firmly grounds SE into the context of its practice to make it meaningful, feasible, and valuable both in the eye of the company and of its stakeholders.

As per the critical appraisal area, SE emerges as a difficult process to tackle with due to its complexity and ambivalent nature, which is characterized by inner contrasting tensions between divergent values, goals and norms to be simultaneously met despite competing demands and ethical dilemmas (Smith, Gonin, \& Besharov, 2013). More specifically SE appears torn between an idealistic impetus on the fringe of a utopian vision of the business, and an often trivial translation into practice urged by the pragmatic necessity to meet accountability requirements and carry out concrete initiatives that allow for dialogue to take place. At present, the emergent conception of SE reveals a corporate sensitivity that is far from that dialogic parity among equal moral partners (Phillips, 1997) that the democratic principles of a legitimation-driven strategic management claim for (Hielscher et al., 2014). The tension between idealism and practical concerns stems from corporate governance logics and organizational 
business models of firms that are often not prone to guarantee the participatory and genuinely dialogic exchange between company and stakeholders advocated by the idealistic moral mandate of SE. In other words SE seems to be constrained by the cage of legal obligations, governance rules, and reporting formats (Herremans, Nazari, \& Mahmoudian, 2016). Even when companies are meeting obligations and rules, they are not apparently enacting genuine SE practices. In that the current process of SE institutionalization is proving fragile by imposing normative rigidity partially neglecting the richness and the relevance of SE context-based nature. Beyond the idealistic and utopian tension of a regulation-free SE, we believe that at least at this early stage of SE translation into practice, exploring the widest contextual variety of SE manifestations is required to orient a more realistic and meaningful institutionalization process capable of accounting also for social emergentism (Powell \& DiMaggio, 1991) and for the interaction between rules and actual actions (Greenwood \& Hinings, 1996). Although presently SE seems to rest upon a functional managerial logic in the way it is conceived and pursued, the dialogic essence characterizing its dynamic tension toward negotiation and sharing between company and stakeholders might act as an enabler of the capability of the firm to account for that social emergentism that is now required to guarantee the selective relevance of the company issues. To cope with the pressure of the regulation cage and the idealistic expectations, virtuous SE practices rely on taking advantage of the discretionary margins of maneuvers to overcome rigid self-referential governance models and one-size fits all rules, grounding SE societal and ethical stances into the socio-cultural context (Selznick, 1996). In this regard, companies led by entrepreneurs and managers who live SE as a natural habitus inspiring all corporate actions open up new discretionary margins to face the institutional constraints (Ingram \& Clay, 2000).

\subsection{Managerial Implications and Future Developments of the Study}

The evidence of this study provides the basis for a couple of managerial implications to be drawn. First of all, for companies that conceive SE as a natural habitus rooted in organizational culture and embed it in strategic decision-making it would be advisable to systematically include SE in the corporate life agenda. That means for instance setting up regular meetings and forums organized as open discussion tables where top executives in charge of the key corporate functions having an impact on business-society relations (e.g. supply chain, production, corporate communication, marketing, sales, finance) confront and agree on a common SE statement and intent declaration that combines in a credible way the moral afflatus of the company with strategic aims. The SE statement, like a competitive positioning statement, needs to be re-defined, negotiated and re-actualized on a regular basis to adjust it in real time to company conditions. These top executive meetings would also serve to identify the strategic guidelines that are necessary to implement the SE statement and intent declaration into daily corporate life beyond the constraints of corporate reporting standards that do not allow to assess the true nature of SE efforts.

In this regard, it would be important to first identify a few Key Performance Indicators (KPIs) of SE that are feasible and measurable. KPIs quantify how well the activities within a SE management process achieved one or more specified goals. KPIs are essential to capture the value created by SE and attempt to link SE with other specific-related performance measures, such as corporate reputation, corporate identity, customer satisfaction, adopted by the firm. Then, once the KPIs are established and agreed on, a set of guidelines on how to implement SE in corporate policies should be identified.

But who in the company should take the lead in setting the agenda as regards SE intent and guidelines? A second managerial implication emerging from this study is that the executive that should act as the SE leader in the company is the CCO (Corporate Communication Officer). Considering the dialogic, confrontational and interpersonal nature of SE pointing at a people-oriented and interactive dimension of relationship management with stakeholders, it is necessary that a highly skilled communication professional takes the lead in setting the agenda of SE meanings and duties inside the firm. The CCO is the executive who is more entailed and more competent in dialogic matters (Gambetti \& Biraghi, 2015) and that can help SE become a distributed-mandate issue in the company, by educating his colleagues of the other units to adopt a stakeholder-sensitive approach in all their decision making. In many companies today new professional figures are proliferating, such as the CSR manager or more recently the SE manager. This since communication professionals are not the first choice when CEOs and board members reflect on those topics (i.e. CSR, SE) and decide new appointments (Zerfass \& Sherzada, 2015). We believe that these new corporate labels do not help prioritizing important issues though, rather they primarily seem to bring fashionable topics of current social appeal inside the company, running the risk of undermining the cogent value of those topics they aim to emphasize. In spite of that, companies should try to make a better use of their actual resources, leveraging on their knowledge, capabilities and skills. The humanistic essence of the CCO entails the seeds of SE in the way stakeholders are listened to, involved and activated in corporate issues (Gambetti \& Biraghi, 2015), which is part of the CCO raison-d'etre in the company. 
This study has some limits. First of all although the research process reached a data saturation with the number of key informants involved, it would be advisable to enrich the scope of the sample to include representatives of other stakeholder groups, such as consumers. Second, considering the co-managed relational nature of SE that emerged from our data, it would be interesting from a methodological standpoint to complement in-depth interviews with focus groups with key informants to frame a view of SE that is socially shared and negotiated among participants. The future developments of this study will be also based on an extensive quali-quantitative content analysis of corporate reporting focused on SE statements and practices with the aim of uncovering how the previously identified tensions between idealism and practical concerns of SE co-exist.

\section{References}

Andriof, J., \& Waddock, S. (2002). Unfolding Stakeholder Engagement. In J. Andriof, S. Waddock, B. Husted, \& S. S. Rahman (Eds.), Unfolding Stakeholder Thinking (pp. 19-42). Sheffield: Greenleaf Publishing Limited.

Aßländer, M. S., \& Curbach, J. (2014). The Corporation as Citoyen? Towards a new understanding of Corporate Citizenship. Journal of Business Ethics, 120(4), 541-554. http://dx.doi.org/10.1007/s10551-013-2004-8

Balmer, J. M. T., Johansen, T. S., \& Ellerup Nielsen, A. (2016). Guest editors' introduction. Scrutinizing Stakeholder Thinking: Orthodoxy or Heterodoxy? International Studies of Management \& Organization, 46(4), 205-215. http://dx.doi.org/10.1080/00208825.2016.1140517

Bhattacharya, C. B., Korschun, D., \& Sen, S. (2009). Strengthening Stakeholder-Company Relationships through mutually beneficial Corporate Social Responsibility initiatives. Journal of Business Ethics, 85(2), 257-272. http://dx.doi.org/10.1007/s10551-008-9730-3

Buchholtz, A. K., \& Carroll, A. B. (2009). Business and society. OH South-Western: Mason.

Burchell, J., \& Cook, J. (2006). It's good to talk? Examining attitude towards Corporate Social Responsibility Dialogue and Engagement process. Business Ethics: a European Review, 15(2), 154-170. http://dx.doi.org/10.1111/j.1467-8608.2006.00439

Cassell, C., \& Symon, G. (2004). Essential guide to Qualitative Methods in Organizational Research. Thousand Oaks, CA: Sage Publications

Coffey, A. J., \& Atkinson, P. A., (1996). Making sense of Qualitative Data: Complementary research strategies. Thousand Oaks, CA: Sage Publications

Corus, C., \& Ozanne, J. L. (2012). Stakeholder Engagement: Building participatory and deliberative spaces in subsistence markets. Journal of Business Research, 65, 1728-1735. http://dx.doi.org/10.1016/j.jbusres.2012.02.014

Crane, A., Matten, D., \& Moon, J. (2004). Stakeholders as citizens? Rethinking rights, participation, and $\begin{array}{lllll}\text { democracy. Journal of Business } & \text { Ethics, } & \text { 53(1-2), } & \text { 107-122. }\end{array}$ http://dx.doi.org/10.1023/B:BUSI.0000039403.96150.b6

Dawkins, C. E. (2014). The principle of Good Faith: toward substantive Stakeholder Engagement. Journal of Business Ethics, 121(2), 283-295. http://dx.doi.org/10.1007/s10551-013-1697-z

Deetz, S. (2008). Engagement as Co-Generative Theorizing. Journal of Applied Communication Research, 36(3), 289-297. http://dx.doi.org/10.1080/00909880802172301

Fukukawa, K., Balmer, J. M. T., \& Gray, E. R. (2007). Mapping the interface between Corporate Identity, Ethics and Corporate Social Responsibility. Journal of Business Ethics, 76(1), 1-5. http://dx.doi.org/10.1007/s10551-006-9277-0

Gambetti, R. C., \& Biraghi, S. (2015). The CCO: appointed or organic leader? The rise of Conversational Leadership. Corporate Communications: an International Journal, 20(4), 415-430. http://dx.doi.org/10.1108/CCIJ-02-2014-0011

Garriga, E. (2014). Beyond Stakeholder utility function: Stakeholder capability in the Value Creation process. Journal of Business Ethics, 120(4), 489-507. http://dx.doi.org/10.1007/s10551-013-2001-y

Glaser, B., \& Strauss, A.L. (1970). Theoretical sampling. In N K. Denzin (Ed.), Sociological methods. A sourcebook (pp. 105-114). New York: McGraw-Hill.

Greenwood, M. (2007). Stakeholder Engagement: beyond the myth of Corporate Responsibility. Journal of Business Ethics, 74(4), 315-327. http://dx.doi.org/10.1007/s10551-007-9509-y

Greenwood, R., \& Hinings, C. R. (1996). Understanding radical organizational change: Bringing together the old 
and the new institutionalism. Academy of Management Review, 21(4), 1022-1054. http://dx.doi.org/10.5465/AMR.1996.9704071862

Hall, N. L., \& Jeanneret, T. (2015). Social license to operate: an opportunity to enhance CSR for deeper communication and engagement. Corporate Communications: an International Journal, 20(2), 213-227. http://dx.doi.org/10.1108/CCIJ-01-2014-0005

Harrison J. S., \& St. John C. H. (1996). Managing and partnering with External Stakeholders. Academy of Management Executive, 10(2), 46-60. http://dx.doi.org/10.5465/AME.1996.9606161554

Harrison, J. S., \& Freeman R. E. (2004). Is Organizational Democracy Worth the Effort? Academy of Management Executive, 18(3), 49-53. http://dx.doi.org/10.5465/AME.2004.14776168

Herremans, I. M., Nazari, J. A., \& Mahmoudian, F. (2016). Stakeholder Relationships, Engagement, and Sustainability reporting. Journal of Business Ethics, 138(3), 417-435. http://dx.doi.org/10.1007/s10551-015-2634-0

Hielscher, S., Beckmann, M., \& Pies, I. (2014). Participation versus Consent. Should corporations be run according to democratic principles?. Business Ethics Quarterly, 4(24), 533-563. http://dx.doi.org/10.5840/beq2014111919

Ingram, P., \& Clay, K. (2000). The choice-within-constraints New Institutionalism and implications for Sociology. Annual Review of Sociology, 26, 525-546. 10.1146/annurev.soc.26.1.525

Johansen, S. T., \& Ellerup N. A. (2011). Strategic Stakeholder Dialogues: a discursive perspective on relationship building. Corporate Communications: an International Journal, 16(3), 204-217. http://dx.doi.org/10.1108/13563281111156871

Leisinger, K. M. (2009). On corporate responsibility on human rights. In H. Spitzeck, M. Pirson, W. Amann, S. Khan, \& E. V. Kimakowitz (Eds.), Humanism in business (pp. 175-203). Cambridge: Cambridge University Press.

Logsdon, J. M., \& Wood, D. J. (2002). Business Citizenship. Business Ethics Quarterly, 12(2), 155-187. http://dx.doi.org/10.2307/3857809

Luoma-aho, V., \& Vos, M. (2010). Towards a more dynamic Stakeholder model: Acknowledging multiple issue arenas. Corporate Communications: an International Journal, 15(3), 315-331. http://dx.doi.org/10.1108/13563281011068159

Matten, D., \& Crane, A. (2005). Corporate Citizenship: Toward an extended theoretical conceptualization. Academy of Management Review, 30(1), 166-179. http://dx.doi.org/10.5465/AMR.2005.15281448

Maxwell, J. A., \& Miller, B. A. (2008). Categorizing and connecting strategies in Qualitative Data Analysis. In S. Nagy Hesse-Biber, P. \& Leavy (Eds.), Handbook of emergent methods (pp. 461-478). New York: The Guilford Press.

Mayan, M. (2009). Essentials of qualitative inquiry. Walnut Creek, CA: Left Coast Press.

Meyer, J. W., \& Rowan, B. (1977). Institutionalised organisations: formal structure as myths and ceremony. Journal of Sociology, 83, 340-363. http://www.jstor.org/stable/2778293

Moon, J., Crane, A., \& Matten, D. (2005). Can Corporations be Citizens? Corporate Citizenship as a metaphor for business participation in Society, Business Ethics Quarterly, 15(3), 429-453. http://dx.doi.org/10.5840/beq200515329

Moriarty, J. (2014). The connection between Stakeholder Theory and Stakeholder Democracy: An excavation and defense. Business \& Society, 53(6), 820-852. http://dx.doi.org/10.1177/0007650312439296

Morse, J. M. (1995). The significance of saturation. Qualitative Health Research, 5(2), 147-149. http://dx.doi.org/10.1177/104973239500500201

Morse, J. M., Stern, P. N., Corbin, J. M., Charmaz, K. C., Bowers, B., \& Clarke, A. E. (2009). Developing Grounded Theory. The Second Generation. Walnut Creek: Left Coast Press.

Noland J., \& Phillips, R. (2010). Stakeholder Engagement, Discourse Ethics and Strategic Management. $\begin{array}{lllll}\text { International Journal of } & \text { Management } & \text { Reviews, } & 12(1),\end{array}$ http://dx.doi.org/10.1111/j.1468-2370.2009.00279.x

O'Dwyer, B. (2005). Stakeholder Democracy: Challenges and contributions from Social Accounting. Business Ethics: A European Review, 14(1), 28-41. http://dx.doi.org/10.1111/j.1467-8608.2005.00384.x 
Palazzo, G., \& Basu, K. (2007). The ethical backlash of Corporate Branding. Journal of Business Ethics, 73(4), 333-346. http://dx.doi.org/10.1007/s10551-006-9210-6

Payne, S. L., \& Calton, J. M. (2002). Towards a Managerial Practice of Stakeholder Engagement. In Andriof, J., Waddock, S., Husted, B. \& Rahman S.S. (Eds). Unfolding Stakeholder Thinking (pp.19-42). New York: Greenleaf Publishing.

Phillips, R. A. (1997). Stakeholder Theory and the principle of Fairness. Business Ethics Quarterly, 7(1), 51-66. http://dx.doi.org/10.2307/3857232

Porter, M. E., \& Kramer, M. R. (2006). Strategy and Society: the link between Competitive Advantage and Corporate Social Responsibility. Harvard Business Review, 84(12), 74-92. Retrieved from http://kantakji.com/media/3307/1135.pdf

Powell, W. W., \& DiMaggio, P. J. (1991). The new institutionalism in organizational analysis. Chicago: University Chicago Press.

Reed, D. (1999). Stakeholder Management Theory: a critical theory perspective. Business Ethics Quarterly, 9(3), 453-483. http://dx.doi.org/10.2307/3857512

Seale, C., Gobo, G., Gubrium, J. F., \& Silverman, D. (2007). Qualitative research practice. London: Sage Publications.

Selznick, P. (1996). Institutionalism "old" and "new". Administrative Science Quarterly, 41(2), 270-277. Retrieved from http://www.jstor.org/stable/2393719

Sison, A. J. G., \& Fontrodona, J. (2012). The common Good of the Firm in the Aristotelian-Thomistic tradition. Business Ethics Quarterly, 22(2), 211-246. http://dx.doi.org/10.5840/beq201222218

Sloan, P., \& Oliver, D. (2013). Building trust in Multi-Stakeholder Partnerships: Critical Emotional Incidents and $\begin{array}{lllll}\text { practices of } \quad \text { Engagement. } & \text { Organization }\end{array}$ http://dx.doi.org/10.1177/0170840613495018

Smith, W. K., Gonin, M., \& Besharov, M. L. (2013). Managing Social-Business tensions: A review and research agenda for Social Enterprise. Business Ethics Quarterly, 23(3), 407-442. http://dx.doi.org/10.5840/beq201323327

Stokes, G. (2002). Democracy and Citizenship. In A. Carter, \& G. Stokes. Democratic theory today (pp. 23-51). Cambridge: Polity Press.

Tracy, S. H. (2013). Qualitative Research Methods: Collecting evidence, crafting analysis, communicating impact. New York: Wiley Blackwell.

Vallaster, C., Lindgreen, A., \& Maon, F. (2012). Strategically leveraging Corporate Social Responsibility to the benefit of Company and Society: A Corporate Branding perspective. California Management Review, 54(3), 34-60. http://dx.doi.org/10.1525/cmr.2012.54.3.34

Waddock, S. (2002). Leading Corporate Citizens: vision, values, value added. Boston: McGraw-Hill.

Waddock, S. (2004). Parallel universes: Companies, academics, and the progress of Corporate Citizenship. Business and Society Review, 109, 5-42. http://dx.doi.org/10.1111/j.0045-3609.2004.00002.x

Wood, D. J., Logsdon, J. M., Lewellyn, P. G., \& Davenport, K. (2006). Global business citizenship. A transformative framework for ethics and sustainable capitalism. Armonk, NY: M.E. Sharpe.

Zerfass, A., \& Sherzada, M. (2015). Corporate communications from the CEO's perspective: how top executives conceptualize and value Strategic Communication. Corporate Communications: an International Journal, 20(3), 291-309. http://dx.doi.org/10.1108/CCIJ-04-2014-0020

\section{List of web references}

Beyond Corporate Social Responsibility: Integrated External Engagement (2013. March). In McKinsey. Retrieved from

http://www.mckinsey.com/business-functions/strategy-and-corporate-finance/our-insights/beyond-corporate -social-responsibility-integrated-external-engagement

Ken dumps Barbies. He doesn't date girls who are into deforestation (2011, June 7). In Greenpeace. Retrieved from http://www.greenpeace.org.uk/blog/forests/ken-dumps-barbie-he-doesnt-date-girls-who-are-deforestation-2 0110607 
Your breakfast is under assult from Climate Change (2014, May 20). In Time. Retrieved from $\mathrm{http} / / /$ time.com/105459/breakfast-cereal-climate-change-oxfam/?iid=sr-link10

Volkswagen the scandal explained (2015, December 10). In $B B C$. Retrieved from http://www.bbc.com/news/business-34324772

The 5 Biggest Corporate Scandals of 2015 (2015, December 27). In Fortune. Retrieved from http://fortune.com/2015/12/27/biggest-corporate-scandals-2015/

Why Trust should matter to every CEO (2016, March 12). In Fortune. Retrieved from http://fortune.com/2016/03/12/bp-oil-john-browne/

How to reinvent External-Affairs function (2016, July). In McKinsey. Retrieved from http://www.mckinsey.com/business-functions/strategy-and-corporate-finance/our-insights/how-to-reinvent-t he-external-affairs-function

\section{Copyrights}

Copyright for this article is retained by the author(s), with first publication rights granted to the journal.

This is an open-access article distributed under the terms and conditions of the Creative Commons Attribution license (http://creativecommons.org/licenses/by/4.0/). 